\title{
Reduction of Environmental Impacts in Crystalline Silicon Photovoltaic Technology: An Analysis of Driving Forces and Opportunities
}

Erik Alsema ${ }^{1}$, and Mariska de Wild-Scholten ${ }^{2}$

${ }^{1}$ Copernicus Institute, Utrecht University, Heidelberglaan 2, Utrecht, Netherlands

${ }^{2}$ Unit Solar Energy, Energy research Centre of the Netherlands (ECN), Westerduinweg 3, Petten, Netherlands

\begin{abstract}
We give an overview of historical developments with respect to the price and the Energy Pay-Back Time of crystalline silicon photovoltaic modules. We investigate the drivers behind both developments and observe that there is a large overlap between them. Reduction of silicon consumption, improved cell efficiency and the production technology for solar grade silicon have been identified as major drivers for both cost and impact reductions in the past. Also we look into future prospects for reduction of environmental impacts. It is estimated that developments underway to reduce costs will also result in a reduction of the Energy Pay-Back Time of a PV installation (in SouthEurope) from 1.5-2.0 year presently to well below 1 year.
\end{abstract}

\section{INTRODUCTION}

In this paper we will look at historical trends in the prices and in Energy Pay Back Time (EPBT) of crystalline silicon PV modules since 1975. The prices are regarded as a proxy for production costs while the EPBT can be considered as good indicator for the environmental imapcts of PV technology. We will identify the drivers that have contributed to the decrease of prices on the one hand and EPBT on the other hand, and investigate the overlap between these drivers. After this historical perspective we will look into future prospects with respect to new c-Si cell concepts and future module production technology and estimate possible reductions in the medium term.

\section{ANALYSIS OF HISTORICAL TRENDS}

Figure 1 shows the development of module prices and module production volumes since 1975 [1-3]. We have added to this graph the Energy Pay-Back Time that can be determined from a number energy analysis or Life Cycle Assessment studies that have been published over the same period [4-8]. The Energy Pay-Back Times have all been calculated for a hypothetical roof-top system in South-Europe with and array-plane irradiation of $1700 \mathrm{kWh} / \mathrm{m} 2 / \mathrm{yr}$ and a Performance Ratio of 0.75 . Energy requirements for Balance-of-System (BOS) components have been assumed the same for all historical data sets, namely $70 \mathrm{MJ}$ (primary energy) per $\mathrm{m}^{2}$ module area for supports and cables and $1300 \mathrm{MJ} / \mathrm{kWp}$ for the inverter. In this way the EPBT values will reflect the developments 
in energy requirements for the modules only ${ }^{1}$. For the data set from Hunt (1976) which did not include energy inputs for the process steps of module assembly and framing we assumed for these steps the same values as given by Hagedorn (1992). Except for the data by Hunt all values are valid for modules based on multicrystalline silicon.

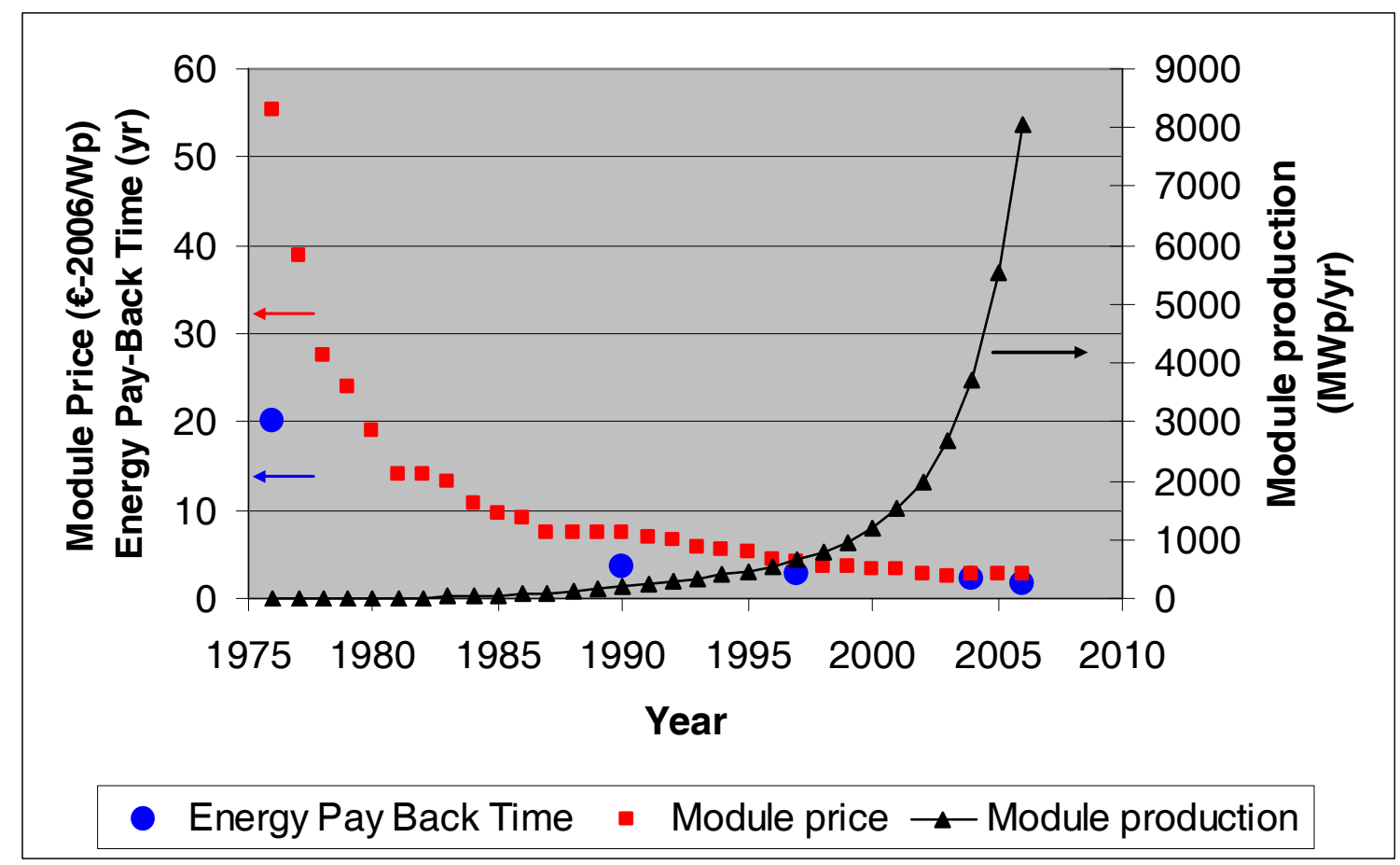

Figure 1: Historical development of module prices (squares, left $\mathbf{y}$-axis, $€-2006 / W p)$, production volumes (triangles, right y-axis; MWp/yr)) and Energy Pay-Back Time (circles, left y-axis, yr). Sources: refs. [1-8]

From the figure we can observe that since 1975 the module price has decreased by a factor 20, while production volume has grown by 25,000x and the Energy Pay-Back Time has gone down with a factor 10 .

As major drivers for the cost reduction we can identify:

- Silicon consumption

- Cell efficiency

- Silicon cost

- Production scale

The next question is which drivers have been behind the reduction in EPBT? For this we need to consider more closely the technology characteristics and results of the individual EPBT studies, as given in figure 2.

One of the first thing that springs to the eye is the large energy input for silicon feedstock in the analysis by Hunt (1976), which cannot be explained only by the

\footnotetext{
${ }^{1}$ Because of these standardized BOS and system performance assumptions and some other corrections EPBT values may differ from those given by the original study. Also note that we placed EPBT values at a time value 1-2 year prior to year of publication so as to reflect better the actual year for which the data are valid.
} 
relatively high silicon consumption of $32 \mathrm{~g} / \mathrm{Wp}$. When we also look at the energy requirements for silicon feedstock in the different studies (table I) we see that this was quite high in the Hunt study and that silicon GER values ${ }^{2}$ remained more or less constant after that. We should add that this value has always been one of the most difficult to estimate because of the complexity of the process, allocation problems and the high confidentiality of process data (see also [Alsema, 1998]).

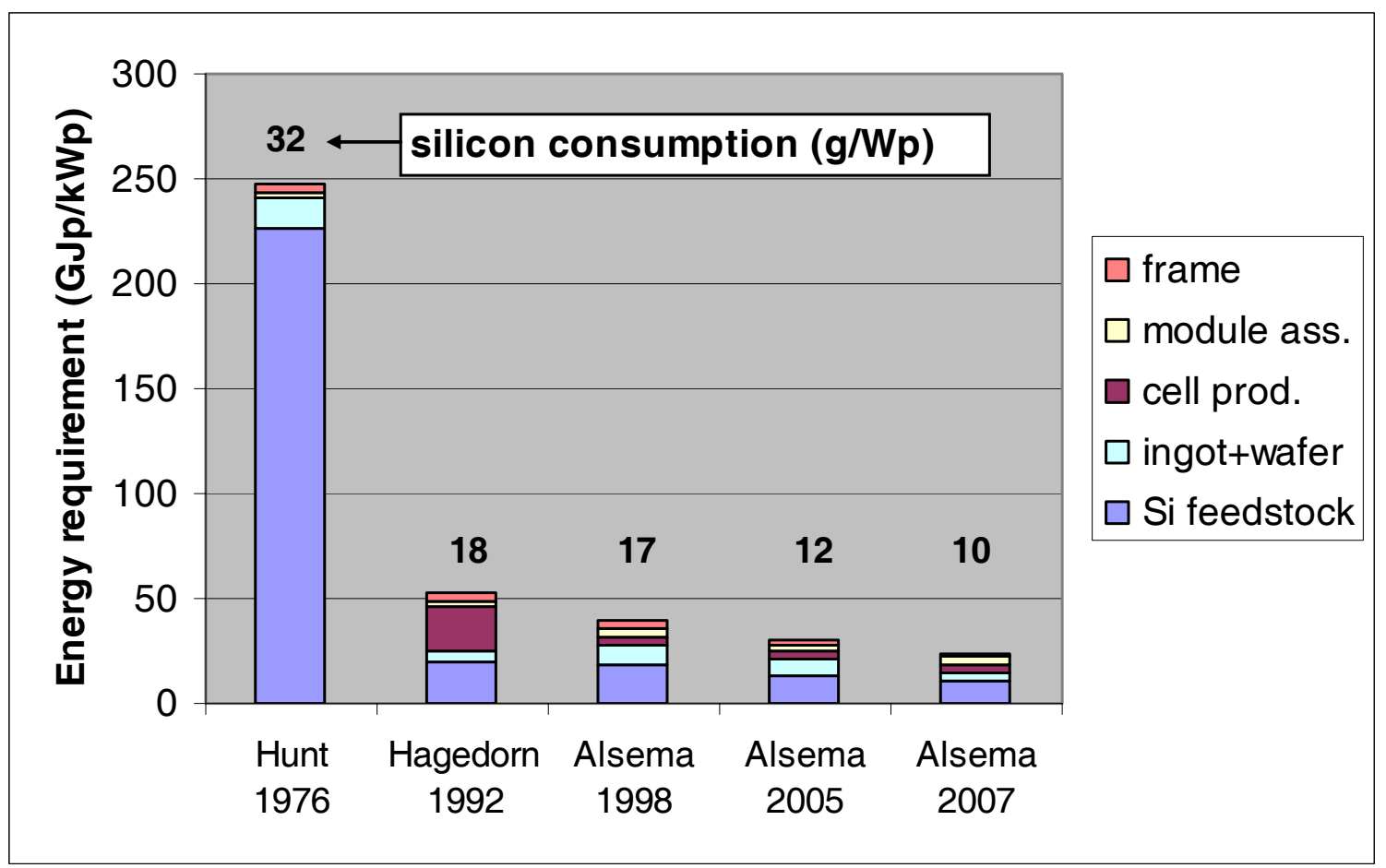

Figure 2: Break-down of energy requirements for multicrystalline silicon modules (in GJ-primary per $\mathrm{kWp}$ ) in different energy analysis studies, together with their year of publication and the amounts of silicon feedstock required per $\mathrm{Wp}$.

Table I: Gross Energy Requirement of solar grade silicon used in each EPBT study

\begin{tabular}{|l|c|}
\hline & $\begin{array}{l}\text { Gross Energy Requirements } \\
\text { for solar-grade silicon }{ }^{1}(\mathrm{MJ} / \mathrm{kg})\end{array}$ \\
\hline Hunt, 1976 & 6700 \\
\hline Hagedorn, 1992 & $1100^{2}$ \\
\hline Alsema, 1998 & 1120 \\
\hline Alsema, 2005 & 1070 \\
\hline Alsema, 2007 & 1070 \\
\hline
\end{tabular}

${ }^{1}$ Electronic grade silicon for the Hunt and Hagedorn studies, solar grade did not exist yet at that time.

${ }^{2}$ Not specified by Hagedorn, estimated by later analysists (see e.g. [9]).

Looking at the results of the period 1992-2007 in more detail (see figure 3) we observe that the feedstock part of the energy input has decreased by almost a factor 2 , solely due to the decreased silicon consumption. Furthermore the cell processing part has

\footnotetext{
${ }^{2}$ GER= Gross Energy Requirement, the cumulative input of primary energy calculated over the whole production chain of a material.
} 
decreased, probably due to increased cell efficiency (i.e. less cell area per Wp) and perhaps due to larger production scales. Between 2005 and 2007 we see a reduced energy input for the ingot and wafering process, which was mostly due to improved wafer yields and better energy efficiency in the casting process. Finally the framing part has decreased, which can mostly be attributed to increased module areas.

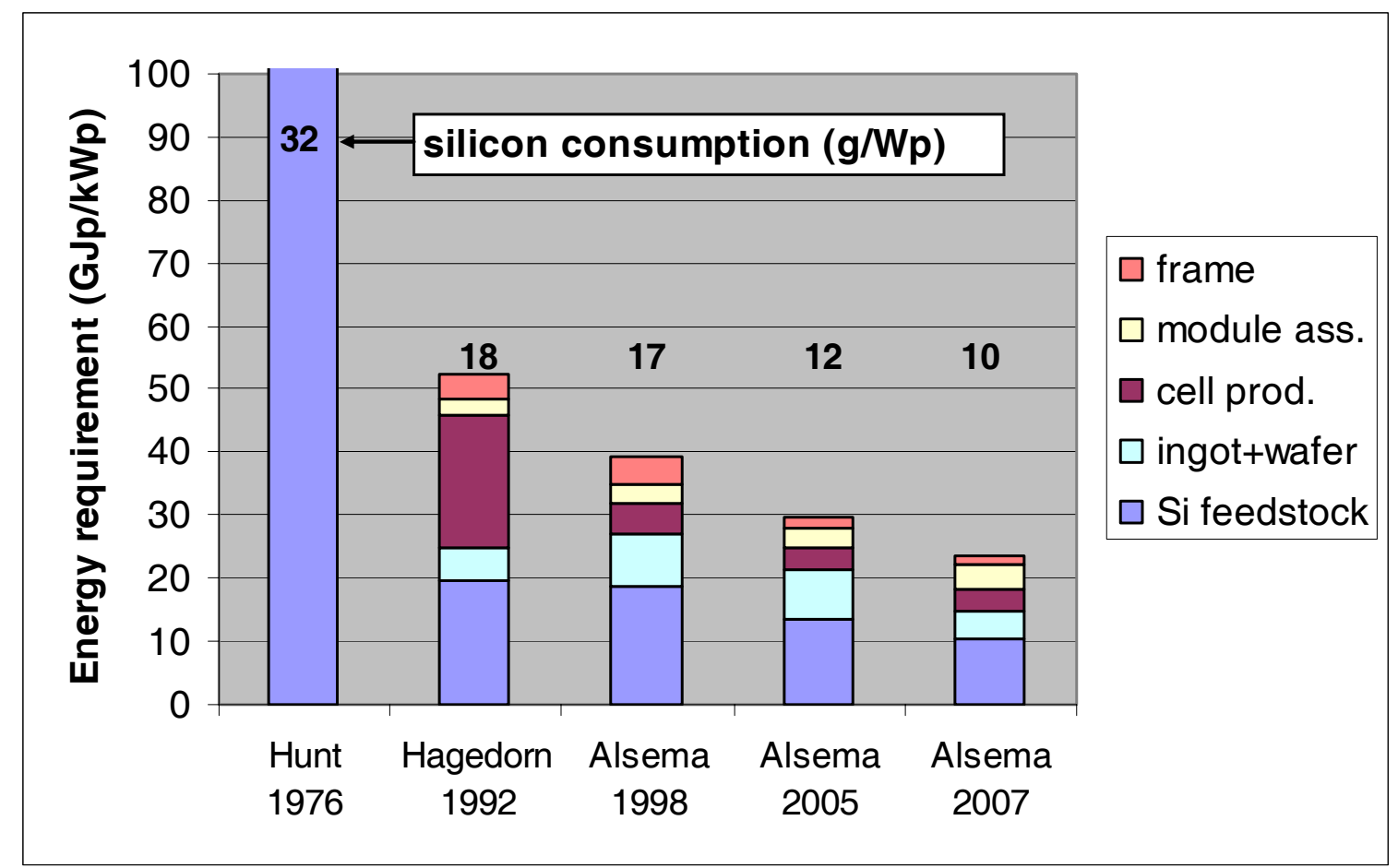

Figure 3: Same as figure 2, but with focus on results 1992-2007

What we learn from this is that the following drivers have been important in the reduction of Energy-Pay-Back Time:

- Silicon consumption

- (Energy input in) silicon feedstock production

- Cell efficiency

- Energy efficiency in casting and other process steps

- (Production scale?)

Comparing the latter set of drivers with those for the price reduction we see that at least three drivers namely silicon consumption, silicon feedstock production and cell efficiency return in both lists. Of course silicon feedstock costs and energy input in silicon feedstock production is quite the same, but energy is certainly a considerable cost factor in silicon production (other than in other module production steps).

This overlap in the drivers for cost and energy reduction implies that efforts to reduce costs per $\mathrm{Wp}$ - which is the most important $\mathrm{R} \& \mathrm{D}$ objective - will in many cases also have beneficial effect on energy pay-back. On the hand we can observe that production scale increase generally has an uncertain effect on energy efficiency, except in casting (lower thermal losses). At the same time it is clear improvements in energy efficiency 
will have small impacts on production cost in wafering, cell processing and module assembly.

\section{ENERGY PAY-BACK TIME FOR PRESENT SITUATION}

Based on our most recent Life Cycle Inventory for the three crystalline silicon technologies, as collected within the Crystal Clear project [10], we can calculate the Energy Pay-Back time for the current technology status (see fig. 4). We see that for a roof-top system in South-Europe the EPBT is respectively 1.5, 1.7 and 2.0 years, depending whether we choose ribbon, multi- and monocrystalline silicon modules.

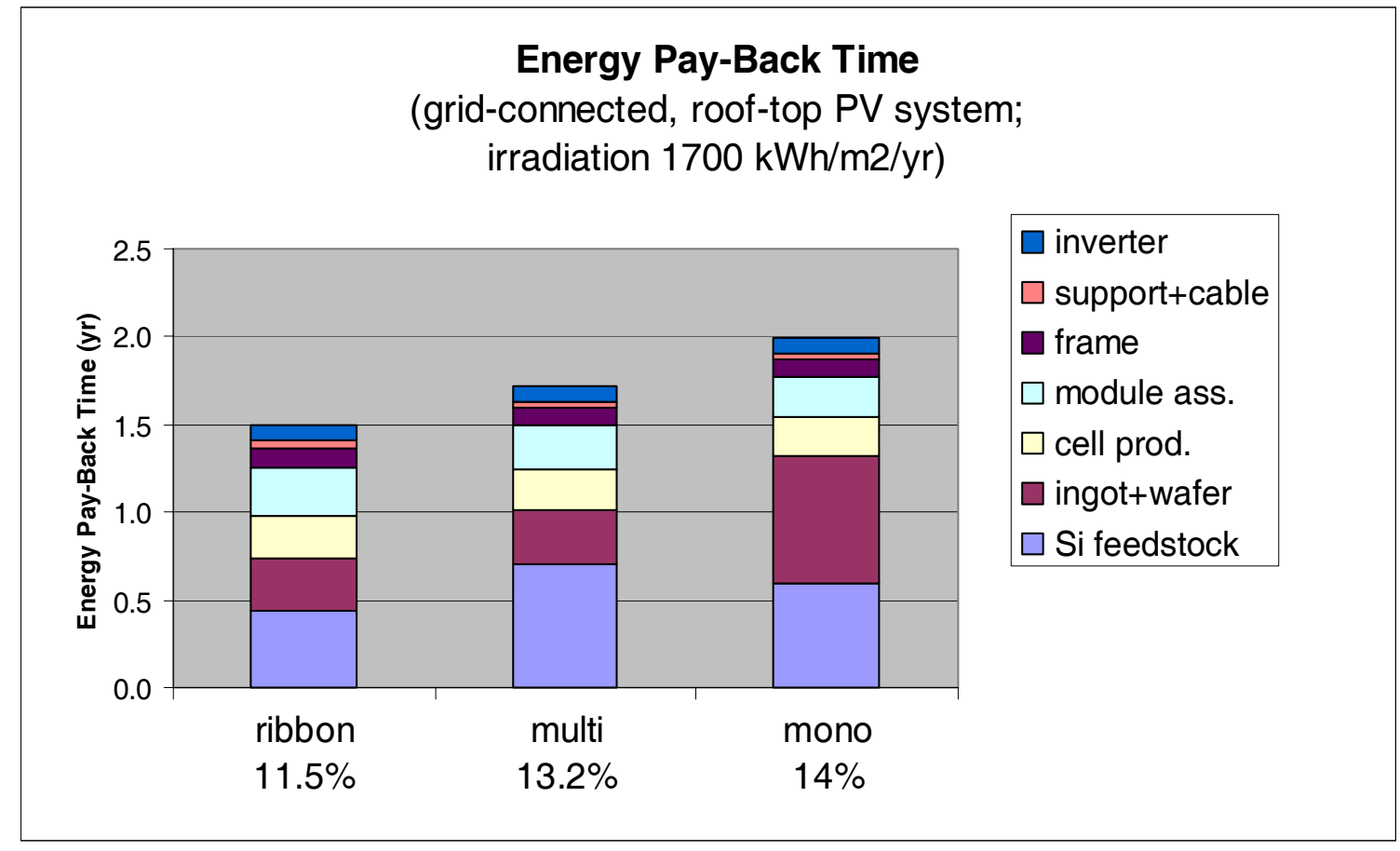

Figure 4: Energy Pay-Back Time of crystalline silicon PV systems in 2006 (rooftop system in S.Europe, irrad. 1700 kWh/m2/yr, PR=0.75).

Of course we can also investigate which opportunities there are for a further reduction of the energy requirement for modules.

\section{PROSPECTS FOR FUTURE REDUCTIONS OF ENERGY REQUIREMENTS}

For our analysis of future prospect we will focus on improvements that relate to the four drivers of energy reduction identified above:

- Reduction of silicon consumption

- Higher cell efficiency

- New Si feedstock processes with lower energy requirements

- Reduced energy consumption for ingot growing. 


\section{New silicon feedstock processes}

We have seen that the process energy for production of poly-Si is responsible for more than $30 \%$ of the total primary energy input for a multi-Si module. On average about $110 \mathrm{kWh}$ of electricity and $185 \mathrm{MJ}$ of heat is used to produce $1 \mathrm{~kg}$ of poly-Si with the improved-Siemens process that is most common at this moment. Because of this high energy consumption energy costs are a significant cost driver, so that new processes, especially for solar grade silicon, are likely to have lower energy consumption.

The process that employs Fluidized Bed Reactors to replace Siemens reactors is reported to have a much lower electricity consumption. Reliable quotes for this technology are hard to come by, but it seems that a reduction to $30 \mathrm{kWh} / \mathrm{kg} \mathrm{Si}$ is possible with FBR. Heat requirements, however, remain more or less the same. The Cumulative Energy Demand of sog-silicon, produced by an improved-Siemens process is estimated at $1070 \mathrm{MJ} / \mathrm{kg}$, while for FBR-silicon we estimate it at about $500 \mathrm{MJ} / \mathrm{kg}$.

For direct metallurgic processes that produce solar grade silicon directly from silica, also heat requirements may be reduced because the step of gas phase distillation is omitted. A published energy estimation for this process is $25 \mathrm{kWh} / \mathrm{kg}(\approx 300 \mathrm{MJ} / \mathrm{kg})$ [11].

Figure 5 gives an indication of the effects that adoption of the FBR process instead of the Siemens process would have on the Energy Pay-Back Time of a PV system based on multicrystalline silicon modules. From the figure it is clear that new feedstock processes can give a dramatic improvement in the environmental profile of PV systems. On top of this other improvements are feasible, as is discussed below.

Barriers for the introduction of new feedstock process are the technological complexity, incomplete understanding of the allowable impurity levels and the high capital requirements for commercial scale plants. However, due to the present silicon scarcity several plants based on new process technology are now under construction.

\section{Reduction of silicon consumption}

The effect of reduced silicon consumption (in $\mathrm{g}$ per $\mathrm{Wp}$ ) has been depicted in figure 5. Observe that silicon consumption has decreased significantly over the past 2 years, driven by the silicon shortage.

Obvious ways to reduce silicon consumption are:

- improved crystallization with lower loss

- thinner wafers

- lower kerf loss

- reduce wafer breakage

- recycling of silicon waste from oingot cut-offs

obroken wafers okerf loss

- casting or pulling wafers directly from liquid $\mathrm{Si}$ (ribbon technologies)

- increased cell efficiency

Almost all of these approaches are already followed within the PV industry and most are also part of the CrystalClear activities. A silicon consumption of 4-6 g/Wp seems to be well in reach within a few years. [12, 13] 
The recycling of silicon kerf loss is - to our knowledge - not done anywhere on a commercial scale, but research on it has been conducted within the FP5 project RE-Si-CLE. If such a process becomes available and does not require too much energy it could substantially reduce silicon consumption by perhaps $30-40 \%$.

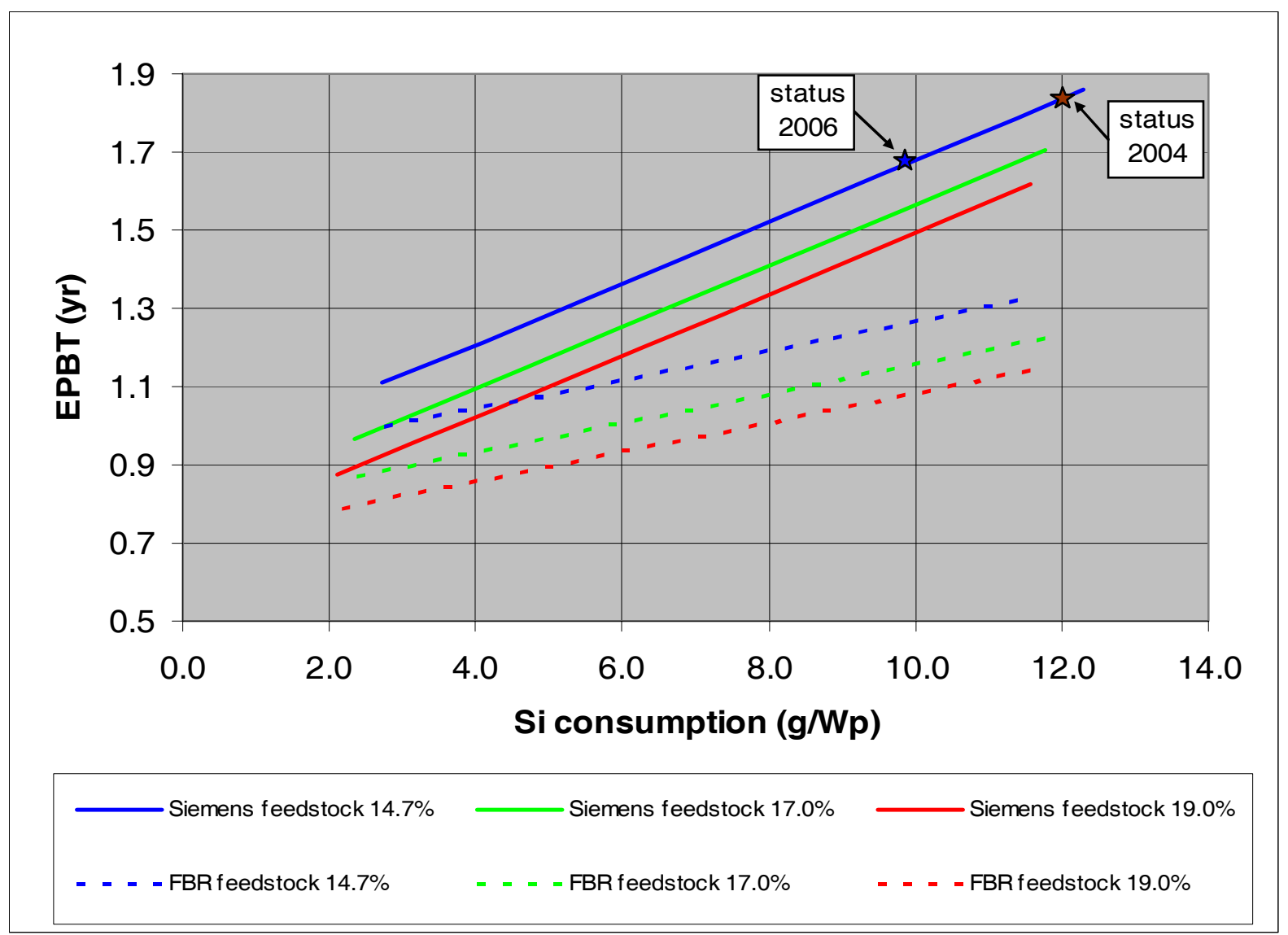

Figure 5: The Energy Pay-Back Time as a function of silicon consumption, for different combinations of a silicon feedstock process (Siemens, FBR) and multi-Si cell efficiency (resp. 14.7\%, 17\%, 19\%). It is assumed that all other material and energy consumption for the module does not change, except that it is directly proportional to the module area. Module type: multi-Si module, frameless. System: roof-top system installed in S-Europe $(1700 \mathrm{kWh} / \mathrm{m} 2 / \mathrm{y})$ with $\mathrm{PR}=0.75$.

Ribbon technologies for producing wafer directly from liquid silicon are in commercial operation and require 7-8 g silicon per $\mathrm{dm}^{2}$, but cell efficiencies are still lower than for conventional wafers at $12.5-14 \%$, so Si consumption per Wp is 5-6 g. For this reason ribbon-Si modules currently have the lowest energy pay-back time (1.5 yr) among all silicon technologies ${ }^{3}$.

Barriers for (further) reduction of silicon consumption are manifold: silicon quality issues (Si recycling), sawing, cell and wafer handling (thinner wafers), cutting wire strength (kerf loss).

\footnotetext{
${ }^{3}$ Note that EPBT values for ribbon technology cannot be derived from Figure 5 because this figure assumes conventional ingot and wafering processes. See [4] for EPBT values of ribbon and other cell technologies.
} 


\section{Increased energy-efficiency in ingot growing}

From figure 5 we have seen that ingot and wafering represent a considerable part of the energy input for a module, especially for mono-Si material. At the same time we have observed that considerable differences in electricity consumption exist which mainly arise in the process of ingot growing. From the background data we also observe a tendency that newer installations have lower electricity consumption. This would imply that there is considerable scope for improvement of the energy efficiency in ingot growing.

One aspect of increased efficiency in newer facilities is probably the larger batch size, which naturally reduces energy losses from the containers of molten silicon.

When looking at the process sequence of the crystal growing process, with its cycle of melting silicon and then slowly cooling it down again, it seems sensible to investigate the possibility of heat recuperation. For example one could think of using the waste heat from the ingot that is cooled down to preheat the next batch of silicon.

Barriers for improved energy efficiency in ingot growing are probably: a lack of urgency (cost advantages unclear), a focus on material quality and long lifetimes of crystal growing equipment.

\section{OUTLOOK}

If we combine a number of improvement options which are already available or will become feasible within the next 3-5 years, we can analyse the total overall improvement that is possible. For this we focus on multicrystalline silicon technology and we assume the use of Fluidized Bed Reactor technology for silicon feedstock material, best available technology for ingot casting, 150 um wafer thickness, $17 \%$ module efficiency and no F-gas emissions. As an extra case we assume that PV operations, from ingot casting to module, will be run on "green" electricity supply, namely wind power. (The FBR feedstock process was in both cases assumed to run on hydropower.)

Figure 6 shows the resulting Energy Pay Back Time (EPBT) and the life-cycle greenhouse gas (GHG) emission for a roof-top PV system in South Europe (irradiation $1700 \mathrm{kWh} / \mathrm{m} 2 / \mathrm{yr}, \mathrm{PR}=0.75$, PV system lifetime $=30$ year $)$. No improvements in BOS or in PR have been assumed. 

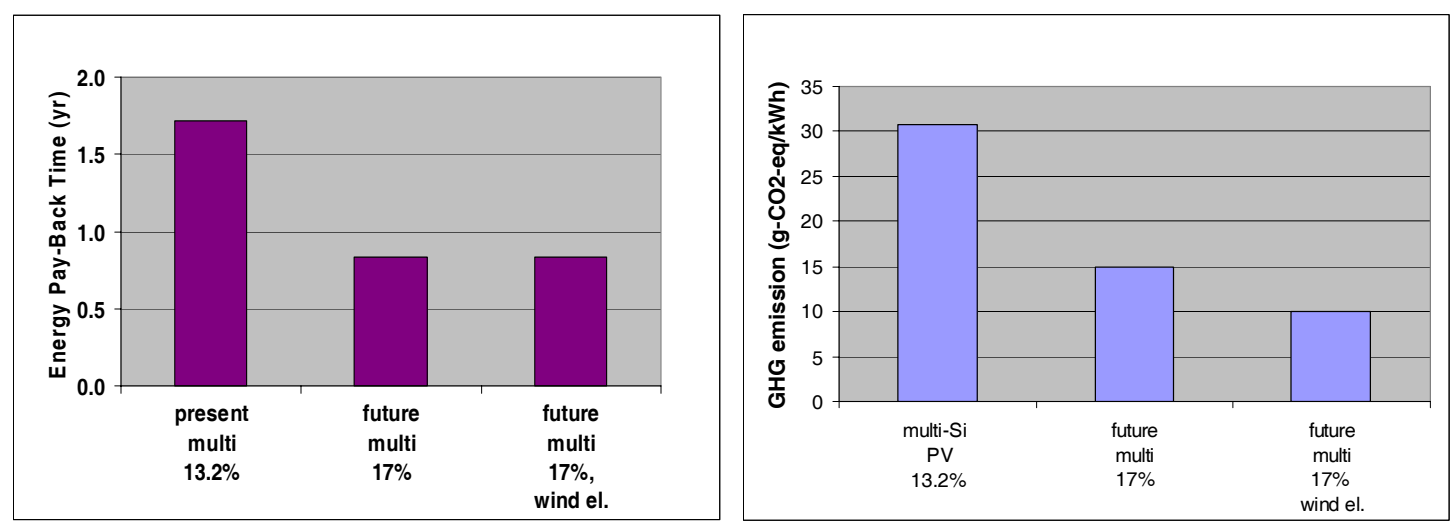

Figure 6: Potential improvements in energy pay-back time (in years, left) and greenhouse gas emissions (in $\mathrm{g} / \mathrm{kWh}$, right) for a multicrystalline silicon roof-top PV system in South Europe (irradiation $1700 \mathrm{kWh} / \mathrm{m} 2 / \mathrm{yr}$ ).

We can see that the EPBT can be reduced by 50\%, to well below 1 year, while the case of wind electricity obviously makes no further difference for the EPBT. With respect to greenhouse gas emissions the present emission of $30 \mathrm{~g} / \mathrm{kWh}$ can be reduced to about 15 $\mathrm{g} / \mathrm{kWh}$, and with the additional switch to green electricity supply even to $10 \mathrm{~g} / \mathrm{kWh}$. At this latter value the GHG emission of c-Si PV technology gets in the same range as wind energy and other low-carbon energy options [14].

\section{CONCLUSIONS}

We have seen that over the last 30 years both the prices and the environmental impacts of crystalline silicon modules have been reduced substantially. It appears that the technological drivers behind both developments show a great overlap. Reduction of silicon consumption, improved cell efficiency and the production technology for solar grade silicon have been identified as major drivers for both cost and impact reduction.

Also we have reviewed a number of options to achieve a further reduction of greenhouse gas emissions in crystalline silicon module production. Altogether we have shown that there are good possibilities to reduce the Energy Pay-Back Time of a multicrystalline silicon PV system from today's 1.7 years to less than 1 year (roof-top system in South Europe). Life-cycle greenhouse gas emissions for such a system can be reduced from $30 \mathrm{~g} / \mathrm{kWh}$ to $15 \mathrm{~g} / \mathrm{kWh}$ or less.

\section{ACKNOWLEDGMENTS}

This study was partly conducted within the framework of the Integrated Project CrystalClear, a research and development project on advanced industrial crystalline silicon PV technology. This project is supported by European Commission under contract number SES6-CT_2003-502583.

For more information on the CrystalClear project: http://www.ipcrystalclear.info/ 


\section{REFERENCES}

1. Strategies Unlimited, Photovoltaic Five-Year Market Forecast 2002-2007, Strategies Unlimited Mountain View, California, USA, 2003.

2. Swanson, RM, A Vision for Crystalline Silicon Photovoltaics, Progress In Photovoltaics: Research and Applications, 2006, 14: p. 443-453.

3. Hirschman, WP, G Hering, and M Schmela, Market survey on global solar cell and module production in 2006, in Photon International, 2007, p. 136-166.

4. Hunt, LP. Total energy use in the production of silicon solar cells from raw materials to finished product, in 12th IEEE Photovoltaic Specialists Conference, Baton Rouge, LA, USA, 1976, p. 347-252.

5. Hagedorn, G. and E. Hellriegel, Umwelrelevante Masseneinträge bei der Herstellung verschiedener Solarzellentypen - Endbericht - Teil I: Konventionelle Verfahren, Forschungstelle für Energiewirtschaft, München, Germany, 1992.

6. Alsema, E.A., P. Frankl, and K. Kato. Energy Pay-back Time of Photovoltaic Energy Systems: Present Status and Prospects, in 2 nd World Conference on Photovoltaic Solar Energy Conversion, Vienna, 6-10 July, 1998

7. Alsema, E. and M.J. Wild-Scholten. Environmental Impacts of Crystalline Silicon Photovoltaic Module Production, in Materials Research Society Fall 2005 Meeting, Warrendale, USA, 2005, Materials Research Society

8. Alsema, E.A. and M.J. de Wild-Scholten. Reduction of the Environmental Impacts in Crystalline Silicon Module Manufacturing, in 22nd European Photovoltaic Solar Energy Conference, Milano, 2007, WIP-Renewable Energies, Munich, Germany

9. Jungbluth, N, Photovoltaics, in Sachbilanzen von Energiesystemen: Grundlagen für den ökologischen Vergleich von Energiesystemen und den Einbezug von Energiesystemen in Ökobilanzen für die Schweiz, Final report ecoinvent v2.0 No. 6, R. Dones, Editor, 2007, Swiss Centre for Life Cycle Inventories: Duebendorf, $\mathrm{CH}$.

10. Wild-Scholten, M.J. de and E.A. Alsema, Environmental Life Cycle Inventory of Crystalline Silicon Photovoltaic Module Production, version 2, status 2005/2006, 2007, ECN, Petten, p. Excel file, http://www.ecn.nl/docs/library/report/2007/e07026-LCIdata-cSiPV-pubv2_0.xls.

11. Friestad, K. in 19th European Photovoltaic Solar Energy Conference, Paris, 2004

12. Aulich, HA and F-W Schulze. Silicon for the PV industry: demand, supply and growth prospects, in 21st European Photovoltaic Solar Energy Conference, Dresden, 2006, p. 549-553.

13. Sinke, WC Crystal Clear roadmap, v3, draft, CrystalClear Consortium, 2006.

14. Alsema, E.A., M.J. de Wild-Scholten, and V Fthenakis. Environmental Impacts of PV Electricity Generation - A Critical Comparison of Energy Supply Options, in 21 st European Photovoltaic Solar Energy Conference, Dresden, 2006, WIPRenewable Energies, Munich, Germany, p. 3201-3207. 